Vol.60: e17160082, January-December 2017 http://dx.doi.org/10.1590/1678-4324-2017160082 ISSN 1678-4324 Online Edition
BRAZILIAN ARCHIVES OF

BIOLOGY AND TECHNOLOGY

AN INTERNATIONAL JOURNAL

\title{
Effect of Partial and Total Replacement of Inorganic by Organic Microminerals Sources on the Quality of Broiler Carcasses
}

\author{
Marcos Lopes ${ }^{1}$, Natalia Paroul ${ }^{2}$, Juliana Barbosa ${ }^{2}$, Eunice Valduga ${ }^{2}$, Rogerio Luis \\ Cansian $^{2 *}$, Geciane Toniazzo ${ }^{2}$, Débora Oliveira ${ }^{3}$. \\ ${ }^{1}$ Aurora Alimentos, Chapecó, Santa Catarina, Brasil; ${ }^{2}$ Universidade Regional Integrada do Alto Uruguai e das \\ Missoes, Campus de Erechim, Erechim, Rio Grandde do Sul, Brasil, ${ }^{3}$ UFSC - Engenharia Quimica e de Alimentos, \\ Florianópolis, Santa Catarina, Brasil.
}

\begin{abstract}
Among the nutrients involved in the chicken diet, the microminerals deserve attention as they exert essential functions in the organism. These compounds can be provided in inorganic (traditional) and organic (chelate) forms. In organic form, the micromimerals can attend a new concept related to a better bio-availability. In this sense, the objective of this work was to evaluate the effect of the partial and total substitution of inorganic by organic sources of microminerals on the animal diet, assessing its concentration in the blood and liver after 21 and 40 days and also in the bones after 40 days. Moreover, the effect on the physical-chemical and sensory characteristics of the muscle after 15 days of storage at $4^{\circ} \mathrm{C}$ was also evaluated. The animals were divided into five treatments: $100 \%$ inorganic, $70 \%$ inorganic and $30 \%$ organic, $50 \%$ inorganic and $50 \%$ organic, $30 \%$ inorganic and $70 \%$ organic and 100\% organic-chelate. It is shown that the use of organic sources of microminerals in the diet of poultry induced to an increase of its concentrations in the blood and liver, with no significant alterations in the compositions of bones, compared to the use of inorganic sources. Feed formulated using 50\% of organic minerals and 50\% of inorganic minerals led to similar results. The diet with organic minerals or mixture with inorganic sources results in a low lipid oxidation in the drumsticks stored at $4^{\circ} \mathrm{C}$ for 15 days, in comparison with those using only inorganic minerals. No sensory alterations were observed for all different treatments.
\end{abstract}

Key words: Bio-availability, Broilers, Microminerals, Nutrition.

\footnotetext{
*Author for correspondence: cansian@uricer.edu.br
} 


\section{INTRODUCTION}

It is well knwon that most of environmental problems in areas of intense poultry production and optimization of poultry performance generally depend on the proper animal nutrition (Ribeiro et al., 2008). Microminerals, especially zinc, manganese and selenium, are considered of great importance in the poultry feeding, once these elements are involved in a series of biochemical mechanisms, of vital relevance to the animal development and growth, mainly osseous formation (Brito et al., 2006; Aksu et al., 2012). Such elements are involved in the immunological system, in the energetic methabolism, among other several phisylogical functions relevant to lide maintainnance and enhancement of animal productivity (Close, 1999).

Over the last years, nutriotinists have used minerals in organic form in an attempt to meet mineral poultry demands, but recentely, a growing interest has been obaserved to organic minerals or chelated sources, frequently described as proteinates. Such latter sources are usually produced after hydrolysis of a proteic source, resulting in the formation of a hydrolyzed matter containing a mixture of aminoacids and peptides of wide size variety (Rutz, 2007).

Several works have discussed the effectiveness of the use of minerals in organic form in replacement of inorganic minerals with different results (Star et al., 2012; Brooks et al., 2013; Liu et al., 2013; Salim et al., 2011; Salim et al., 2012; Wang et al., 2012; Brooks et al., 2012). Consequently, organically complexed minerals will continue to be an important issue for current research focuses on understanding the mechanisms and impacts of organically complexed trace minerals on meat quality (Aksu et al., 2012). The Association of American Feed Control Officials (AAFCO, 2000) determines rules and standards for the food intended to animal production, in which the organic minerals are metallic ions chemically bond to an organic molecule, forming structures with unique characteristics of stability and having high mineral bio-availability.

These metals are commonly found in many forms, from complex organic compounds to salts of varied solubility. In the organic form, minerals are absorbed by intestinal carriers of amino-acids and peptides and not by classical intestinal transporters. This prevents the competition among minerals by the same absorption mechanism. Thus, not only bio-availability becomes superior but also minerals in organic form are readly transported to the tissues, where they are kept stored for a a longer time compared to inorganic minerals. However, chelate minerals are usually more expensive when compared to those coming from inorganic sources and traditionaly, an inclusion increase in these inorganic sources is consired much cheaper.

The substitution of inorganic sources by organic minerals in broiler is generally not associated with the improvement of zoo-technical standards, but instead in the parameters observed in the poultries, for the whole chickens and also with the improvement verified in animal carcasses (Costa et al., 2010). The microminerals, especially selenium, has a significant impact in the animal performance and animal immunity, inducing physiological changes in muscular tissue, which can in turns positively affect cattle and chicken meat quality (Hess et al., 2003). This fact may be explained in terms of the improved bio-availability of organic minerals and the action of selenium as a co-factor of glutathione peroxidase and zinc and manganese as co-factors of dismutase super-oxide enzyme, hence acting as preventive antioxidants, comprising an important enzymatic defense system against free-radicals and cellular and intra-cellular membranes attacks (Rover et al., 2001).

In this context, taking into account that nutrition represents $60 \%$ of chicken production cost, the main objetive of this work was to investigate the comparative 
Quality of Broiler Carcasses with Organic Microminerals

effect of partial and total substitution of inorganic by organic sources ( $\mathrm{Zn}, \mathrm{Se}$ and $\mathrm{Mn}$ ) on the animal diet and its concentration in the blood, liver and bones and also its effects on muscle physicochemical characteristics (TBARS, pH, acidity and aw) and sensorial analyses.

\section{MATERIAL AND METHODS}

\section{Packaging and Experimental Design}

Chickens were grown for 40 days in an experimental unity with 2,520 male Cobb chicken used, housed a one day old, with an average weight of $42 \mathrm{~g}$.

\section{Treatment description}

Hereafter, T1- means 100\% inorganic - control; T2- 70\% inorganic and 30\% organic; T3- 50\% inorganic and 50\% organic; T4- 30\% inorganic and 70\% organic; T5- $100 \%$ organic (chelate).

\section{Microminerals determination}

Determination of microminerals ( $\mathrm{Se}, \mathrm{Zn}$ and $\mathrm{Mn}$ ) was carried out through blood and liver collecting from, following the procedure describe in AOAC (1990). Blood collect was performed at 21 and 40 days of life, by means of three (03) chicken sacrifice by each treatment, ramdomly chosen in the boxes. Such matterial was obtained by cardiac puncture in controlled environment temperature. Serum was transferred to specific recipients and then submitted to mineral analysis, with the following procedure: in $0.1 \mathrm{~g}$ of sample, $1.5 \mathrm{~mL} \mathrm{H}_{2} \mathrm{SO}_{4}$ was added, conducting to a digester at $150{ }^{\circ} \mathrm{C}$ during $30 \mathrm{~min}$; t then, it was added $2.5 \mathrm{~mL}$ of hydrogen peroxide heated for $1 \mathrm{~h}$ at $150^{\circ} \mathrm{C}$ or up to sample clarifying, it was cold and added $2.0 \mathrm{~mL}$ of $\mathrm{HNO}_{3}$, heating during $1 \mathrm{~h}$ at $150^{\circ} \mathrm{C}$. Afterwards, MilliQ water was carefully added through tube walls to promote sample dilution. The lectures were carried out in atomic absorption (Varian - SpectrAA 55).

\section{Determination of microminerals in bones}

Samples of bones from tibias were placed in forced air-circulating stove at $65^{\circ} \mathrm{C}$ for $72 \mathrm{~h}$, afterwards $1 \mathrm{~mm}$ sieved-milled and packaged in glass flasks. The content of zinc, copper and manganese was determined by flamme atomic spectrophotometry (Varian SpectrAA-220), as described by Milles et al. (2001).

\section{Physicochemical and sensory analysis of meat}

In order to follow the oxidative stability of meat during the storage period, analysis of TBARS, $\mathrm{pH}$ and acidity of thighs and drumsticks for $0,7,10$ and 15 days of storage under refrigeration $\left(4^{\circ} \mathrm{C}\right)$.

Concomitantly, sensory analysis was carried out using drumstick muscle at 0,5 and 12 days of refrigeration storage.

In both cases, sample from three treatments were analyzed: $100 \%$ inorganic; $50 \%$ inorganic and $50 \%$ organic and $100 \%$ organic in and attempt to better express the goal of this work, elucidating possible effect differences between organic and inorganic minerals.

To evaluate the lipid oxidative level of crude samples during storage, the reactive test of 2 tiobarbituric acid (TBA) was employed in accordance with the work of Raharjo et al. (1992). Values of TBARS were determined by triplicate of each sample and results were expressed in $\mathrm{mg}$ of malonaldehyde per $\mathrm{kg}$ of sample. 
For $\mathrm{pH}$ determination, it was employed $10 \mathrm{~g}$ of samples together with $20 \mathrm{~mL}$ of deionized water and homogenized by $1 \mathrm{~min}$; $\mathrm{pH}$ values were recorded by a digital potentiometer (Digimed®), previously calibrated at $\mathrm{pH} 4$ and 7 (AOAC, 1990).

For acidity determination, $10 \mathrm{~g}$ of sample was diluted in $200 \mathrm{~mL}$ of distilled water, triturated during $1 \mathrm{~min}$ and transferred to volumetric flask of $250 \mathrm{~mL}$, then filling to $250 \mathrm{~mL}$ and filtering the resulting solution. It was then transferred $25 \mathrm{~mL}$ of the filtered solution to an Erlenmeyer and added $75 \mathrm{~mL}$ of distilled water, together with 3 drops of $1 \%$ alcoholic phenolphthalein solution and then titration with $\mathrm{NaOH} 0.1 \mathrm{~N}$ $(\mathrm{pH}=8.2)$. Total acidity was expressed as grams of oleic acid per $100 \mathrm{~g}$ of sample.

The water activity (aw) was determined following the procedure of Aqualad CX-2 Water Activity - System, by calibrating the equipment with deionized water and $\mathrm{NaCl}$ at 0.819 of aw up to stabilization and finally recording aw/temperature.

Sensory analysis was carried out in laboratory scale, with 10 trained tasters from both sexes, different age groups (20 to 50 years old). Samples ( $2 \mathrm{~cm}$ edges) were distributed in plastic recipients, identified with random numbers of three digits together with the evaluation forms. Sensory experiment was conducted following a balanced incomplete block design of type I with a reference-standard in each block, with 10 tasters in two sensory evaluation sections (in natura and roasted samples). Each taster evaluated for each section, three samples and expressed how the reference-standard sample diverged from the treated sample, on mixed scale of 9 points (0- none difference; 2 - slightly different; 4- moderately different; 6-much different, 8- extremely different). For in natura samples, color and odor were evaluated based on the related attributes while for roasted samples aroma, color, taste, texture were considered. Roasted samples were prepared in conventional electric oven at around $200{ }^{\circ} \mathrm{C}$ during approximately $45 \mathrm{~min}$ without the addition of salt or any other spices.

\section{Statistical Analysis}

Experimental data were submitted to statistical variance analysis (ANOVA) and also with regard to mean values (Tukey test, $5 \%$ ) using the Software Statistica ${ }^{\circledR} 7.0$ (Statsoft - INC®. USA). The regression analysis and fitting procedure were performed through Microsoft Excel software.

\section{RESULTS}

\section{Analysis of microminerals from blood and liver}

Results regarding the content of zinc, manganeses and selenium in the liver and blood of chicken submitted to treatment with inorganic and organic minerals are presented in Tables 1, 2 and 3, respectively.

It can be seen from these tables that the content of zinc in chicken blood with 21 days life varied in the range of 41.1 to $82.6 \mathrm{mg} / \mathrm{kg}$. Clearly, treatment $3(50 \%$ inorganic and $50 \%$ organic) was significantly superior $(\mathrm{p}<0.05)$ than other treatments. For 40 days life, the content decreased in all treatments, varying from 27.7 to $31 \mathrm{mg} / \mathrm{Kg}$, with no statiscal differences verified amon them.

In liver samples of 21 days the highest zinc content were obtained with treatments 5 (100\% organic) and 4 (30\% inorganic and $70 \%$ organic), whereas for 40 days, the greastet zinc content was observed in treatment 5 . 
Quality of Broiler Carcasses with Organic Microminerals

Table 1. Content of $\mathrm{Zn}(\mathrm{mg} / \mathrm{kg})$ present in blood and liver of poultry submitted to treatment with organic and inorganic minerals.

\begin{tabular}{|c|c|c|c|c|}
\hline \multirow{3}{*}{ Treatment } & \multicolumn{4}{|c|}{ Zinc content (mg/kg) } \\
\hline & \multicolumn{2}{|c|}{ Blood } & \multicolumn{2}{|c|}{ Liver } \\
\hline & 21 days & 40 days & 21 days & 40 days \\
\hline \multicolumn{5}{|l|}{$\mathrm{T}$} \\
\hline $1-100 \%$ inorganic & $42.6^{\mathrm{b}} \pm 5.9$ & $31.0^{\mathrm{a}} \pm 4.5$ & $46.2^{\mathrm{b}} \pm 2.9$ & $49.8^{\mathrm{b}} \pm 3.2$ \\
\hline $\mathrm{T}-70 \%$ inorganic and $30 \%$ & & & & \\
\hline 2 organic & $50.7^{\mathrm{b}} \pm 19.8$ & $30.0^{\mathrm{a}} \pm 3.8$ & $42.5^{\mathrm{b}} \pm 9.2$ & $41.7^{\mathrm{c}} \pm 2.7$ \\
\hline $\mathrm{T}-50 \%$ inorganic and $50 \%$ & & & & \\
\hline 3 organic & $82.6^{\mathrm{a}} \pm 28.1$ & $27.7^{\mathrm{a}} \pm 4.7$ & $47.7^{\mathrm{b}} \pm 6.1$ & $48.8^{\mathrm{b}} \pm 3.6$ \\
\hline $\mathrm{T}-30 \%$ inorganic and $70 \%$ & & & & \\
\hline 4 organic & $41.1^{\mathrm{b}} \pm 23.9$ & $29.2^{\mathrm{a}} \pm 5.2$ & $51.1^{\mathrm{ab}} \pm 3.7$ & $41.0^{c} \pm 4.6$ \\
\hline $\mathrm{T}$ & & & & \\
\hline $5-100 \%$ organic & $38.8^{\mathrm{b}} \pm 10.0$ & $29.9^{\mathrm{a}} \pm 6.0$ & $65.4^{\mathrm{a}} \pm 10.0$ & $56.8^{\mathrm{a}} \pm 5.3$ \\
\hline
\end{tabular}

The content of manganese in blood evaluated at 21 days differed significantly $(\mathrm{p}<0.05)$ only for treatment $3,23.5 \mathrm{mg} / \mathrm{kg}$ (Table 2$)$. At 40 days it can be noticed na increase trend of manganese content in blood as a consequence of the increase in organic to inorganic minerals ratio, with statistical difference after treatment 3 . With regard to liver samples, a significant difference was observed in manganese content only for treatment 5 (100\% organic) in relation to other treatments for the samples of 21 days. In the liver at 40 days, no significant differences were noted for the treatment with Mn.

Table 2. Content of $\mathrm{Mn}(\mathrm{mg} / \mathrm{kg})$ present in blood and liver of poultry submitted to treatment with organic and inorganic minerals.

\begin{tabular}{|c|c|c|c|c|}
\hline \multirow{3}{*}{ Treatment } & \multicolumn{4}{|c|}{$\begin{array}{l}\text { Manganese content } \\
(\mathrm{mg} / \mathrm{kg})^{*}\end{array}$} \\
\hline & \multicolumn{2}{|c|}{ Blood } & \multicolumn{2}{|c|}{ Liver } \\
\hline & 21 days & 40 days & 21 days & 40 days \\
\hline \multicolumn{5}{|l|}{$\mathrm{T}$} \\
\hline $1-100 \%$ inorganic & $19.1^{\mathrm{b}} \pm 8.3$ & $14.5^{\mathrm{b}} \pm 2.4$ & $14.2^{\mathrm{b}} \pm 5.0$ & $17.4^{\mathrm{a}} \pm 3.2$ \\
\hline $\mathrm{T}-70 \%$ inorganic and $30 \%$ & & & & \\
\hline 2 organic & $19.3^{b} \pm 9.2$ & $16.3^{\mathrm{b}} \pm 2.4$ & $12.3^{\mathrm{b}} \pm 3.3$ & $13.4^{\mathrm{a}} \pm 5.1$ \\
\hline $\mathrm{T}-50 \%$ inorganic and $50 \%$ & & & & \\
\hline 3 organic & $23.5^{\mathrm{a}} \pm 5.7$ & $17.0^{\mathrm{ab}} \pm 5.0$ & $11.2^{\mathrm{b}} \pm 3.8$ & $15.6^{\mathrm{a}} \pm 5.8$ \\
\hline $\mathrm{T}-30 \%$ inorganic and $70 \%$ & & & & \\
\hline 4 organic & $18.2^{\mathrm{b}} \pm 6.1$ & $17.7^{\mathrm{ab}} \pm 4.3$ & $13.8^{\mathrm{b}} \pm 5.0$ & $13.4^{\mathrm{a}} \pm 8.0$ \\
\hline $\mathrm{T}$ & & & & \\
\hline $5-100 \%$ organic & $19.7^{b} \pm 6.4$ & $22.1^{\mathrm{a}} \pm 3.9$ & $17.6^{\mathrm{a}} \pm 9.2$ & $17.4^{\mathrm{a}} \pm 3.4$ \\
\hline
\end{tabular}

*Means ( \pm standard deviation) followed by equal lower case letters on the column do not differ statistically at a confidence level of 95\% (Tukey's test).

Inspection of Table 3 shows that a greater absorption of selenium in blood at 21 days for the higher ratios of organic minerals (treatments 3 to 5), but at 40 days equal mineral mixture (50\% inorganic and 50\% organic) presented the highest contents. Such result was also observed in the liver analysis at 21 days. At 40 days, all treatments that presented oraganic minerals exhibited selenium contents greater that the treatments with $100 \%$ inorganic minerals. 
Table 3. Content of Se present in the blood and liver of poultry submitted to the treatment with organic and inorganic minerals.

\begin{tabular}{|c|c|c|c|c|}
\hline \multirow{3}{*}{ Treatment } & \multicolumn{4}{|c|}{ Selenium content $(\mathrm{mg} / \mathrm{kg})^{*}$} \\
\hline & \multicolumn{2}{|c|}{ Blood $(\mu \mathrm{g} / \mathrm{L})$} & \multicolumn{2}{|c|}{ Liver $(\mathrm{mg} / \mathrm{kg})$} \\
\hline & 21 days & 40 days & 21 days & 40 days \\
\hline \multicolumn{5}{|l|}{$\mathrm{T}$} \\
\hline $1-100 \%$ inorganic & $0.067^{\mathrm{b}} \pm 0.006$ & $0.075^{\mathrm{b}} \pm 0.006$ & $3.45^{\mathrm{b}} \pm 0.28$ & $1.56^{\mathrm{b}} \pm 0.24$ \\
\hline $\mathrm{T}-70 \%$ inorganic and $30 \%$ & & & & \\
\hline 2 organic & $0.067^{\mathrm{b}} \pm 0.007$ & $0.082^{\mathrm{b}} \pm 0.004$ & $3.73^{\mathrm{b}} \pm 0.44$ & $1.75^{\mathrm{ab}} \pm 0.21$ \\
\hline $\mathrm{T}-50 \%$ inorganic and $50 \%$ & & & & \\
\hline 3 organic & $0.071^{\mathrm{ab}} \pm 0.007$ & $0.087^{\mathrm{a}} \pm 0.002$ & $4.23^{\mathrm{a}} \pm 0.82$ & $2.35^{\mathrm{a}} \pm 0.69$ \\
\hline $\mathrm{T}-30 \%$ inorganic and $70 \%$ & & & & \\
\hline 4 organic & $0.073^{\mathrm{ab}} \pm 0.008$ & $0.078^{\mathrm{b}} \pm 0.003$ & $3.90^{\mathrm{b}} \pm 0.80$ & $1.70^{\mathrm{ab}} \pm 0.15$ \\
\hline $\mathrm{T}$ & & & & \\
\hline $5-100 \%$ organic & $0.083^{\mathrm{a}} \pm 0.009$ & $0.083^{\mathrm{b}} \pm 0.002$ & $3.85^{\mathrm{b}} \pm 0.45$ & $2.10^{\mathrm{ab}} \pm 0.15$ \\
\hline
\end{tabular}

\section{Analysis of microminerals from bones}

Table 4 shows the results concerning the content of zinc, manganese and copper in ash of chickens submitted to organic and inorganic minerals, where one can see that no statistical differences $(\mathrm{p}<0.05)$ were verified among treatments tested.

Table 4. Content of $\mathrm{Zn}, \mathrm{Mn}$ and $\mathrm{Cu}(\mathrm{mg} / \mathrm{kg})$ present in the ash of poultry bones submitted to the treatment with organic and inorganic minerals.

\begin{tabular}{|c|c|c|c|c|}
\hline \multirow{2}{*}{ Treatment } & \multirow{2}{*}{$\begin{array}{c}\text { Fat-free ash } \\
(\mathrm{g} / 100 \mathrm{~g})\end{array}$} & \multicolumn{3}{|c|}{$\begin{array}{l}\text { Micromineral } \\
(\mathrm{mg} / \mathrm{kg})^{*}\end{array}$} \\
\hline & & Mn & $\mathrm{Cu}$ & Zn \\
\hline \multicolumn{5}{|l|}{$\mathrm{T}$} \\
\hline $\begin{array}{l}1-100 \% \text { inorganic } \\
\mathrm{T}-70 \% \text { inorganic and } 30 \%\end{array}$ & $50.76^{\mathrm{a}} \pm 2.23$ & $9.85^{\mathrm{a}} \pm 0.57$ & $10.57^{\mathrm{a}} \pm 0.88$ & $374.32^{\mathrm{a}} \pm 2.29$ \\
\hline 2 organic & $51.93^{\mathrm{a}} \pm 0.60$ & $9.87^{\mathrm{a}} \pm 0.90$ & $9.82^{\mathrm{a}} \pm 1.01$ & $388.55^{\mathrm{a}} \pm 33.11$ \\
\hline $\mathrm{T}-50 \%$ inorganic and $50 \%$ & & & & \\
\hline 3 organic & $50.09^{\mathrm{a}} \pm 0.78$ & $9.35^{\mathrm{a}} \pm 0.74$ & $10.00^{\mathrm{a}} \pm 0.36$ & $386.38^{\mathrm{a}} \pm 27.73$ \\
\hline $\mathrm{T}-30 \%$ inorganic and $70 \%$ & & & & \\
\hline 4 organic & $49.63^{\mathrm{a}} \pm 1.14$ & $9.93^{\mathrm{a}} \pm 1.39$ & $10.42^{\mathrm{a}} \pm 0.60$ & $389.88^{\mathrm{a}} \pm 36.02$ \\
\hline $\mathrm{T}$ & & & & \\
\hline $5-100 \%$ organic & $50.58^{\mathrm{a}} \pm 1.71$ & $9.89^{\mathrm{a}} \pm 0.55$ & $10.54^{\mathrm{a}} \pm 0.89$ & $373.74^{\mathrm{a}} \pm 31.80$ \\
\hline
\end{tabular}

Physical-chemical analysis

Table 5 presents the time course of lipid oxidation (TBARS) in samples of raw drumsticks chicken submitted to treatment with organic and inorganic minerals kept under refrigeration at $4{ }^{\circ} \mathrm{C}$ during 15 days, considering three treatments $(100 \%$ inorganic, $50 \%$ organic and $50 \%$ inorganic and $100 \%$ organic). 
Quality of Broiler Carcasses with Organic Microminerals

Table 5. Lipid oxidation (TBARS) of broiler chicken drumsticks submitted to treatment with organic and inorganic minerals (100\% inorganic, $50 \%$ inorganic and $50 \%$ organic and $100 \%$ organic) cooled at $4^{\circ} \mathrm{C}$ during 15 days.

\begin{tabular}{|c|c|c|c|c|}
\hline \multirow{2}{*}{ Treatment } & \multicolumn{4}{|c|}{$\begin{array}{l}\text { TBARS (mg of MDA/kg of } \\
\text { sample)* }\end{array}$} \\
\hline & 0 days & 7 days & 10 days & 15 days \\
\hline$\overline{\mathrm{T}}$ & & & & \\
\hline $1-100 \%$ inorganic & $0.13^{\mathrm{aC}} \pm 0.04$ & $0.42^{\mathrm{aB}} \pm 0.03$ & $0.49^{\mathrm{aA}} \pm 0.03$ & $0.57^{\mathrm{aA}} \pm 0.09$ \\
\hline $\begin{array}{l}\mathrm{T}-50 \% \text { inorganic and } 50 \% \\
3 \text { organic } \\
\mathrm{T}\end{array}$ & $0.11^{\mathrm{aB}} \pm 0.05$ & $0.19^{\mathrm{bB}} \pm 0.03$ & $0.33^{\mathrm{bA}} \pm 0.04$ & $0.31^{\mathrm{bA}} \pm 0.02$ \\
\hline $5-100 \%$ organic & $0.14^{\mathrm{aB}} \pm 0.07$ & $0.12^{\mathrm{bB}} \pm 0.02$ & $0.31^{\mathrm{bA}} \pm 0.03$ & $0.32^{\mathrm{bA}} \pm 0.10$ \\
\hline
\end{tabular}

It can be noted that the three treatments showed similar behavior at zero day TBARS evaluation, a different situation verified at 7 days, in which treatment 1 (100\% inorganic) presented higher TBARS value $(0.42 \mathrm{mg}$ of $\mathrm{MDA} / \mathrm{kg})$ compared to the other treatments. The same situation occurred at 10 and 15 days of evaluation, as a significant increase $(\mathrm{p}<0.05)$ was observed in TBARS contents at storage conditions related to samples of treatment 1.

Values regarding $\mathrm{pH}$ (6.16 to 6.82$)$ and acidity ( 0.11 to 0.18$)$ did not present significant differences ( $p>0.05)$ among treatments in the period 0 to 15 days in which drumsticks were kept under refrigeration at $4^{\circ} \mathrm{C}$.

\section{Sensory analysis}

With regard to sensory characteristics it was noted that (sobrecoxas) samples of in natura chicken treated with different mineral sources did not present statistical differences $(p>0.05)$ in relation to aroma and color among treatments of $100 \%$ inorganic; $50 \%$ organic and 50\% inorganic and $100 \%$ organic for 15 days storage under refrigeration, attributing no difference in scale for the aroma attribute and slightly different concerning color. The same behavior was observed for the attributes of aroma, taste, texture and color of roasted drumsticks chicken submitted to treatment with organic and inorganic minerals storage at $4{ }^{\circ} \mathrm{C}$ during 15 days, leading to no difference and slightly different attributes decision.

\section{DISCUSSION}

According to Kratzer and Vohra (1996), extra supplementation of minerals aiming at increase the animal's availability may cause deleterious effects like diarrhea and imbalances that might lead to reduction of availability of some other minerals. Besides, inhibition of minerals absorption by other substances and/or nutrients when in inorganic form, such as oxalic and folic acids, tannins, fibers, among others. Nevertheless, chelate minerals present better absorption compared to inorganic ones as, in general, they use the absorption ways of organic molecules in which they are bond hence does not causing interactions restriction with other minerals. The mechanism through which the chelating agent improves minerals use depends on the ligand ability towards minerals scavenging, or on its ability to form other soluble complexes with the minerals.

It was observed a higher zinc concentration in blood at 21 days with a mixture of $50 \%$ of organic and inorganic minerals, whereas in the liver, at the same period of 
treatment, with organic minerals in relation to inorganic ones, this trend was not observed at 40 days.

According to Lowe et al. (1991), the content of zinc in blood serum is commonly used to evaluate the concentration of this mineral in the human organism, but for animals in stress state, zinc reduction in serum may occur, though not associated to the deficiency of zinc and hence this may not be an adequate parameter to assess zinc demands, once it is not only affected by the diet. With regard to organic zinc, Tucker (2008) argues that a better performance of chicken supplemented with such mineral is associated with its greater availability. It is kwon that the absorption place of zinc in animals is the small intestine. The main excretion route is the liver through faeces, with only small amounts delivered through urine. The main storage form of zinc is as metallothionein in the liver and its synthesis is induced by the presence of such element in the liver (McDowell, 1992).

Blood analysis at 40 days and liver at 21 days showed high content values of manganeses in treatment 5 (100\% organic), which just corroborates the theory of better bio-availability of organic minerals. Manganeses is an essential mineral to chicken development, especially for bone development. Two diseases are reported to come from the lack of such mineral: perose and bone chondrodystrophies, caused by manganese deficiency (Lyons and Insko, 1937).

One of the specific actions of manganese is the mucopolysaccharides synthesis (present in cartilage) and the dismutase superoxide, which was isolated from chicken liver mitochondria (Leach, 1971). Lack of manganese was associated to depression of immunity and central nervous system (Hurley, 1981). Rossi et al. (2007) in investigating the effect of organic minerals on the performance of reproductive system of heavy matrixes concluded that supplementation of manganese in the form of aminoacid complex diminished the initial mortality of chicks without affecting the carcass characteristics.

The higher concentrations of selenium were observed to occur in the presence of organic minerals thus evidencing the greater bio-availability in such form. These results show that a mixture of organic and inorganic minerals lead to a better use of selenium by chicken from the ccomodation up to the period of 40 days life. Upton (2003) states that the two selenium forms, organic and inorganic, may be used as dietary supplement although they differ considerably about physicochemical properties and also regarding absorption and metabolism. During the absorption, selenomethionine is actively transported through intestinal membranes and is accumulated in the liver and muscles. The inorganic selenium absorbed as mineral is less retained in the tissues, with the major part being excreted.

Yoon et al. (2007) studied the effect of organic and inorganic sources of selenium on the performance of chicken matrixes and concluded that different sources did not affect their performance and development, though older chickens retain a more amount of selenium and its use is more efficient when present in lower concentrations in the diet. The authors also reported that organic selenium form exhibited greater bio-availability than the inorganic form, evidencing its retention and staying in blood.

According to Santos et al. (2005) selenium is essential for correct maintainance of several organic functions, like reproduction, growth, and disease prevention as well as to keep the tissues integrity. The metabolic function of selenium is closely connected to vitamin $\mathrm{E}$, as both act protecting biological membranesagainst degenerative oxidation. In that work, authors investigated the antioxidant factors of organic selenium in the performance of hen and observed that the morphology of the chicken oviduct supplemented with organic selenium presented better preservation of the structures responsible for internal and external quality of eggs, hence leading to a global improvement of chcken organism. 
Quality of Broiler Carcasses with Organic Microminerals

The deposition of minerals in tibia as an answer to diet supplementation is a very used parameter and its sensitivity has demonstrated better results compared to other evaluation accomplished in other organs and tissues like liver, kidneys, pancreas and blood. However, in the present work, no significant differences were observed concerning the amount of minerals (copper, manganese and zinc) in tibias evaluated for 6 the different treatments. These results agree with those found by Brito et al. (2006), in assessing the minerals utilization in organic complex form for chikens within the period of 7 to 12 weeks on the performance and bone charateristic. These authors found no significant differences among treatments in terms of performance and uniformity, while with a redcution in the inclusion levels of organic supplement there was a linear decrease in ash content of chicken tibias, though no difference was found between inorganic (control) and organic sources.

Some works on layers, like that of Boruta et al. (2006), in which the performance of layer chicken fed with organic minerals in different levels, concluded that the bone resistance increased and excretion was reduced in all groups. According to Mariutti and Bragagnolo (2009), chicken meat is highly susceptible to lipid oxidation due to the existent high content of unsaturated fatty acids. The formation of cholesterol oxides and degradation of fatty acids, mainly the poly-unsaturated ones, in addition to the volatile secondary compounds coming from lipid oxidation, may be one of the most important factors responsible for the quality and nutritional losses.

Regarding the lipid oxidation, it was observed a significant increase of TBARS values in treatment 1 (100\% inorganic) in comparison with other treatments, though a significant increase was also verified for all treatments from 10 days chicken storage. Such observation may be explained in terms of greater bio-availability of organic minerals together with the selenium action as cofactor of glutathione peroxidase enzyme and zinc and manganese as cofactors of dismutase superoxide enzyme, acting, according to Rover et al. (2001), as preventive anti -oxidants, comprising a relevant enzymatic defense system against the attack of free radicals to cellular and intra-cellular membranes.

Boiago (2013) evaluated the performance, carcass yield and qualitative characteristics of chicken breast meat fed with supplemented diets with different concentrations and sources of selenium and concluded that the organic selenium sources afforded lower meat oxidation at the experimental conditions investigated. The authors also observed that higher supplementation of selenium led to an increase of ash percentage in meat.

$\mathrm{Lu}$ et al. (2007), in studying the effect of source and levels of manganese on the quality of drumsticks chicken, abdominal fat and lipid oxidation, observed that organic manganese sources were more efficient in reducing the activity of liprotein enzyme over abdominal fat of chickens, hence diminishing abdominal fat deposition.

The $\mathrm{pH}$ measurement may be used as evaluation proof/test of meat conservation step, due to the production of amines and ammonia, since a gradual $\mathrm{pH}$ increase takes place after rigor mortis setup. The $\mathrm{pH}$ interval found in this work did not present significant differences and remained close to those reported in the literature (Santos et al., 2005).

\section{CONCLUSIONS}

The use of orgaic sources of microminerals ( $\mathrm{Zn}, \mathrm{Mn}$ and $\mathrm{Se}$ ) in broilers diet conducted to an increase in their concentrations in blood and liver, but with no alterations in bone composition compared to the diet with inorganic minerals form. Feed formulated with 50\% organic and 50\% inorganic minerals afforded similar 
results. The diet with organic minerals or mixtures with inorganic minerals led to lower lipid oxidation of drumsticks stored at $4^{\circ} \mathrm{C}$ for 15 days compared to the diet with uinorganic minerals. Sensory alterations were not experimentally verified through treatments employed in this work.

\section{ACKNOWLEDGMENTS}

The authors thank CNPq, FAPERGS and CAPES for the financial support and scholarships.

\section{REFERENCES}

1. AAFCO. Association of American Feed Control Officials. 2000; http://www.aafco.org/Home.aspx. Accessed in $6^{\text {th }}$ October, 2013.

2. AOAC. Association of Official Analytical Chemists: Official methods of analysis of the AOAC. 15 ed. Arlington, Virginia, EUA; 1990. 1250p.

3. Aksu DS, Aksu T, Önel SE. Does inclusion at low levels of organically complexed minerals versus inorganic forms create a weakness in performance or antioxidant defense system in broiler diets? Int J Poultry Sci. 2012; 11: 666-672.

4. Boiago MM, Borba H, Souza PA, Scatolini AM, Ferrari FB, Giampietro-Ganeco A. Performance of broilers fed diets containing different sources of selenium, zinc and manganese reared under thermal stress conditions. Arq Bras Med Vet Zootec, 2013; 65: 241-247.

5. Boruta A, Swierczewska E, Glebocka K, Nollet L. Minerals (Bioplex) as total replacement of inorganic sources for layers - effect on productivity. In: $23^{\circ}$ Symposium Annual of Alltech. Lexington, Ky. 2006.

6. Brito JAG, Bertechini AG, Fassani EJ, Rodrigues PB, Freitas RTF. Effects of feeding trace minerals as organic complex for replacement pullets in the period from 7 to 12 weeks old. Rev Bras Zootec, 2006; 35: 1342-1348.

7. Brooks MA, Grimes JL, Lloyd KE, Valdez F, Spears JW. Relative bioavailability in chicks of manganese from manganese propionate. The J Appl Poult Res, 2012; 21: 126130.

8. Brooks MA, Grimes JL, Lloyd KE, Verissimo S, Spears JW. Bioavailability in chicks of zinc from zinc propionate. The J Appl Poult Res, 2013; 22: 153-159.

9. Close WH. Organic minerals for pigs: update. In: Biotechnology in the feed industry, proceedings of Alltech's 15th annual Symposium. Ed. Lyons, TP, Jacques KA. Nottingham University Press, UK. 1999. 51-60.

10. Costa FGP, Silva JHV, Lima RC, Oliveira CFS, Rodrigues VP, Pinheiro, SG. Scientific progress in the production of monogastric in the first decade of the twentyfirst century. R Bras Zootec, 2010; 39: 288-302.

11. Hess JB, Downs KM, Bilgili SF. Selenium nutrition and poultry meat quality. Nutritional Biotechnology in the feed and food industries. In: Proceedings of Altech's $19^{\text {th }}$ International Symposium. Nottingham University Press, United Kingdom. 2003. 107-112.

12. Hurley LS. Teratogenic effects of manganese, zinc and copper in nutrition. Physiol Rev, 1981; 61: 249-295.

13. Kratzer FH, Vohra P. 1996. Chelates and chelation. In: Chelates in nutrition. Boca Raton, Florida: CRC Press, 1996. 5-33.

14. Leach RM. 1971. Role of manganese in mucopolysaccharide metabolism. Fed Proceed, 1971; 30: 991-994.

15. Liu SB, Li SF, Lu L, Xie JJ, Zhang LY, Wang RL, Luo XG. The effectiveness of zinc proteinate for chicks fed a conventional corn-soybean meal diet. The J Appl Poult Res, 2013; 22: 396-403.

16. Lowe NM, Bremer I, Jackson MJ. Plasma ${ }^{65}$ Zn kinetics in the rat. Br J Nutr, 1991; 65: 445-455. 
Quality of Broiler Carcasses with Organic Microminerals

17. Lu L, Luo XG, Ji C, Liu B, Yu SX. Effect of manganese supplementation and source on carcass traits, meat quality, and lipid oxidation in broiler. J Anim Sci, 2007; 85: 812822.

18. Lyons M, Insko WM. Chondrodystrophy in the Chick Embryo Produced by Manganese Deficiency in the Diet of the Hen. Bulletin 371, Agricultural Experiment Station, Kentucky, USA. 1937.

19. Mariutti LRB, Bragagnolo N. Lipid oxidation of chicken meat and the impact of the addition of sage (Salvia officinalis, L.) and garlic (Allium sativum, L.) as natural antioxidants. Rev Inst Adolfo Lutz, 2009; 68: 1-11.

20. Mcdowell LR. Minerals in animal and human nutrition. Department of Animal Science. University of Florida. 1992. 524p.

21. Milles PH, Wilkinson NS, Mcdowell LR. Analysis of minerals for animal nutrition research. 3 ed. Gainesville, University of Florida. 2001. 118p.

22. Raharjo S, Sofos NJ, Schmidt RG. Improved speed, specificity, and limit of determination of an aqueous acid extraction thiobarbituric acid- $\mathrm{C}_{18}$ method for measuring lipid peroxidation in beef. J Agric Food Chem, 1992; 40: 2182-2185.

23. Ribeiro AML, Vogt LK, Canal CW, Laganá C, Streck AF. 2008. Vitamins and organic minerals supplementation and its effect upon the immunocompetence of broilers submitted to heat stress. Rev Bras Zootec, 2008; 37: 636-644.

24. Rossi P, Rutz F, Anciuti MA, Rech JL, Zauk NHF. Influence of graded levels of organic zinc on growth performance and carcass traits of broilers. J Appl Poult Res, 2007; 16: 219-225.

25. Rover L Jr, Hoehr NF, Vellasco AP, Kubota LT. Antioxidant system involving the glutathione metabolic cycle associated to electroanalytical methods in the oxidative stress evaluation. Quim Nova, 2001; 24: 112-119.

26. Rutz F, Anciuti MA, Rech JL, Xavier EG. Following response to Sel-Plex ${ }^{\circledR}$ and other organic minerals trough the broiler breeder maze: case studies in Brazil. In: Proceedings Altech's $22^{\text {th }}$ Annual Symposium on Biotechnology in feed Industry. Ed. Lyons TP, Jacques, KA. Nottingham University Press, Southborough, UK. 2006. 502-513.

27. Santos AL, Sakomura NK, Freitas ER, Fortes CMLS, Carilho ENVM, Fernandes JBK. Growth, performance, carcass yield and meat quality of three broiler chickens strains. Rev Bras Zootec, 2005; 34: 1589-1598.

28. Salim HM, Lee HR, Jo C, Lee SK, Lee BD. Supplementation of graded levels of organic zinc in the diets of female broilers: effects on performance and carcass quality. Brit Poult Sci, 2011; 52: 606-612.

29. Salim HM, Lee HR, Jo C, Lee SK, Lee BD. Effect of sex and dietary organic zinc on growth performance, carcass traits, tissue mineral content, and blood parameters of broiler chickens. Biol Trace Elem Res, 2012; 147: 120-129.

30. Star L, Van Der Klis JD, Rapp C, Ward TL. Bioavailability of organic and inorganic zinc sources in male broilers. Poult Sci, 2012; 91: 3115-3120.

31. Tucker L. Trace minerals in poultry nutrition-3 Redefining mineral nutrition- What we've learned so far. World Poult, 2008; 4: 18-19.

32. Upton JR. The effects of selenium supplementation on performance and antioxidant enzyme activity in broiler chickens. Thesis. Department Nutrition and Poultry Science. North Carolina State University, Raleigh, North Carolina, USA. 2003.

33. Wang F, Lu L, Li S, Liu S, Zhang L, Yao J, Luo X. Relative bioavailability of manganese proteinate for broilers fed a conventional corn - soybean meal diet. Biol Trace Elem Res, 2012; 146: 181-186.

34. Yoon I, Werner TM, Butler JM. Effect of source and concentration of selenium on growth performance and Selenium retention in Broiler Chickens. Poult Sci, 2007; 86: 727-730. 